Revista Brasileira de Agricultura Irrigada v.12, nº.5, p. 2907 - 2922, 2018

ISSN 1982-7679 (On-line)

Fortaleza, CE, INOVAGRI - http://www.inovagri.org.br

DOI: $10.7127 /$ rbai.v12n500866

Protocolo 866.18 - 06/01/2018 Aprovado em 14/09/2018

\title{
INFLUÊNCIA DE NÍVEIS FREÁTICOS NOS PARÂMETROS PRODUTIVOS E FISIOLÓGICOS DA CULTURA DO RABANETE
}

Antonio Vanklane Rodrigues de Almeida ${ }^{1}$, Márcio Facundo Aragão ${ }^{2}$, Humberto Gildo de Sousa $^{1}$, Francisco Mardones Sérvulo Bezerra ${ }^{1}$, Alexsandro Oliveira da Silva ${ }^{3}$

\section{RESUMO}

O encharcamento do solo é um problema para agricultura, principalmente para culturas de ciclo curto como o rabanete, devido a sua susceptibilidade ao excesso de água no solo. Diante disto, um experimento foi realizado com o objetivo de avaliar o rendimento da cultura do rabanete sob diferentes níveis freáticos. O delineamento experimental utilizado foi o de blocos casualizados com cinco tratamentos: lençol freático mantido constante nas profundidades de 5 , $10,20,30 \mathrm{~cm}$ e um tratamento testemunha (sem a presença de lençol freático) e 6 repetições, totalizando assim 30 unidades experimentais. Para tanto, foram utilizados tanques de drenagem durante dois ciclos de produção (03/05/17 à 02/06/17 e 20/06/17 à 20/07/2017), onde foram analisadas variáveis de rendimento como: diâmetro médio da raiz, massa fresca da parte aérea e raiz, massa seca da parte aérea e raiz, além de trocas gasosas como: taxa de fotossíntese líquida, condutância estomática, transpiração e temperatura foliar. Os dados foram submetidos a análise de variância e posteriormente ao teste de Tukey a 5\% de probabilidade. A maioria das variáveis estudadas apresentaram redução nos seus valores à medida que o lençol freático se aproximou da superfície, o tratamento com nível freático de $20 \mathrm{~cm}$ de profundidade apresentou condições favoráveis ao desenvolvimento da cultura.

Palavras-chave: Drenagem agrícola, Raphanus Sativus L., excesso hídrico.

\section{INFLUENCE OF WATER LEVELS IN THE YIELD AND PHYSIOLOGICAL PARAMETERS OF RADISH CULTIVATION}

\footnotetext{
ABSTRACT

Excess water in the soil is very damaging to crops, especially fast-cycle crops as radish, which is very susceptible to excess water in the soil. In view of this, an experiment was conducted

${ }^{1}$ Eng. Agrônomo, Discente do Programa de Pós-Graduação em Engenharia Agrícola da UFC, Fortaleza - CE, Email: vanklaneprece@hotmail.com, humbertosousa71@hotmail.com,

${ }^{2}$ Tecnólogo em Irrigação e Drenagem, Discente do Programa de Pós-Graduação em Engenharia Agrícola da UFC, Fortaleza - CE, E-mail: marcioaragao26@gmail.com

${ }^{3}$ Eng. Agrônomo, Docente do Programa de Pós-Graduação em Engenharia Agrícola da UFC, Fortaleza - CE, Email: alexsandro@ufc.br
} 
with the objective of evaluating the yield of the radish crop under different phreatic levels. The experimental design was a randomized block with five treatments: constant phreatic levels at the depths to $5,10,20,30 \mathrm{~cm}$ and a control treatment (without the presence of water table) and 6 replications, totaling 30 experimental units. For this, drainage tanks were used during two seasons crops (05/03/17 to 06/02/2017 and 06/20/17 to 07/20/2017), were analyzed yield variables: root diameter, fresh mass of root and aerial part, dry mass of root and aerial part. Gas exchanges were analyzed: liquid photosynthesis rate, stomatal conductance, transpiration and leaf temperature. The data submitted to the test $\mathrm{F}$ and later to the Tukey teste to $5 \%$ of probability. Most of the studied variables presented a reduction in their values as the water table approached the soil surface. The treatment with phreatic level of $20 \mathrm{~cm}$ of depth presented conditions favorable to the development of the culture.

Keywords: Agricultural drainage, Raphanus Sativus L., water excess.

\section{INTRODUÇÃO}

O excesso de água assim se apresenta como um fator negativo na agricultura, afetando principalmente culturas com sistemas radiculares de pequeno desenvolvimento como as hortaliças. Tal problema está geralmente associado a elevação do lençol freático, ocasionado por chuvas intensas ou em função do excesso de irrigação (ARAGÜÉS et al., 2011).

O excesso de água é um dos fatores mais restritivos para a produção de muitas culturas, seja reduzindo o estande ou o desenvolvimento de cada planta, segundo Mundstock et al. (2017) na ausência de uma drenagem eficiente, a utilização de cultivares que sejam tolerantes ao excesso hídrico pode ser uma opção para obtenção de maiores produtividades.

O rabanete (Raphanus sativus L.) é originário da região mediterrânea da Europa, mostra-se como uma cultura bastante expressiva em algumas regiões do Brasil, sendo utilizada em saladas e na fabricação de conservas. Essa cultura vem ganhando destaque entre os olericultores, principalmente por apresentar características atraentes, como ciclo curto e rusticidade, sendo a colheita realizada de 25 a 35 dias após a semeadura (FILGUEIRA, 2008). É produzida principalmente por pequenos e médios olericultores, localizados nos cinturões verdes das grandes cidades (OLIVEIRA et al., 2010).

De acordo com Silva et al. (2012), o rabanete tem a sua parte comercializável localizada na camada subsuperficial do solo, sendo o seu rendimento afetado pelo excesso de água no solo, segundo Costa et al. (2006), variações de umidade e temperatura no solo durante o desenvolvimento das plantas de rabanete podem prejudicar a produtividade e a qualidade das raízes, tais afirmações foram comprovadas por Costa et al. (2008) em estudos com a cultura da beterraba, onde estes autores observaram reduções no rendimento total da cultura de acordo com aproximação do lençol freático na superfície do solo. Para Pereira et al. (1999), o estresse hídrico ao longo do ciclo da cultura pode alterar seu desenvolvimento, modificando a fisiologia, morfologia e, principalmente, afetando as relações bioquímicas da planta.

Diante do exposto, este trabalho tem como objetivo avaliar o efeito de diferentes profundidades do lençol freático no desenvolvimento e rendimento da cultura do rabanete.

\section{MATERIAL E MÉTODOS}

O experimento foi realizado durante os meses de maio a junho de 2017 no Departamento de Engenharia Agrícola da Universidade Federal do Ceará (altitude de 20 m, $3^{\circ} 44^{\prime} 43,11^{\prime \prime}$ de latitude Sul e $38^{\circ} 34^{\prime}$ 51,83” de longitude Oeste). O clima da região é do tipo AW', tropical chuvoso, conforme classificação Köppen, com precipitação média anual de $1.350 \mathrm{~mm}$ concentrada nos meses de janeiro a abril, temperatura média anual de $26,5^{\circ} \mathrm{C}$, média mínima de $23^{\circ} \mathrm{C}$ e máxima de 
$29,3^{\circ} \mathrm{C}$, insolação de 2870 horas anuais e umidade relativa do ar de $80 \%$.

A área do experimento apresenta solo classificado como Luvissolo, com relevo suave ondulado e declividade máxima de $2,5 \%$. Sua textura é franco-arenosa e franco-argilo- arenoso (EMBRAPA, 2013), para as camadas de 0 a $0,25 \mathrm{~m}$ (A) e de 0,25 a $0,50 \mathrm{~m}$ (B) respectivamente, sendo suas características físicas mostradas na Tabela 1 , enquanto a Tabela 2 é demonstrada as características químicas do solo da área experimental.

Tabela 1. Características físicas do solo da área experimental

\begin{tabular}{ccccccc}
\hline \multirow{2}{*}{$\begin{array}{c}\text { Camada } \\
(\mathrm{m})\end{array}$} & $\begin{array}{c}\text { Areia Grossa } \\
(\%)\end{array}$ & $\begin{array}{c}\text { Areia fina } \\
(\%)\end{array}$ & $\begin{array}{c}\text { Silte } \\
(\%)\end{array}$ & $\begin{array}{c}\text { Argila } \\
(\%)\end{array}$ & $\begin{array}{c}\text { Argila natural } \\
(\%)\end{array}$ & Classificação textural \\
\cline { 2 - 5 } & 40 & 37 & 10 & 13 & 2 & Franco-arenoso \\
$0-0,25$ & 19 & 43 & 12 & 26 & 1 & Franco-argilo-arenoso \\
\hline Camada (m) & Grau de & \multicolumn{2}{c}{ Densidade $\left(\mathrm{g} \mathrm{cm}^{-3}\right)$} & Ucc (\%peso) & Upmp (\% peso) \\
\cline { 2 - 5 } & Floculação & \multicolumn{2}{c}{ solo } & Partículas & & \\
\hline $0-0,25$ & 92 & 1,47 & 2,69 & 7,0 & 4,2 \\
$0,25-0,50$ & 96 & 1,37 & 2,63 & 11,6 & 8,0 \\
\hline
\end{tabular}

Ucc - umidade na capacidade de campo, Upmp - umidade no ponto de murcha permanente

Tabela 2. Características químicas do solo da área experimental

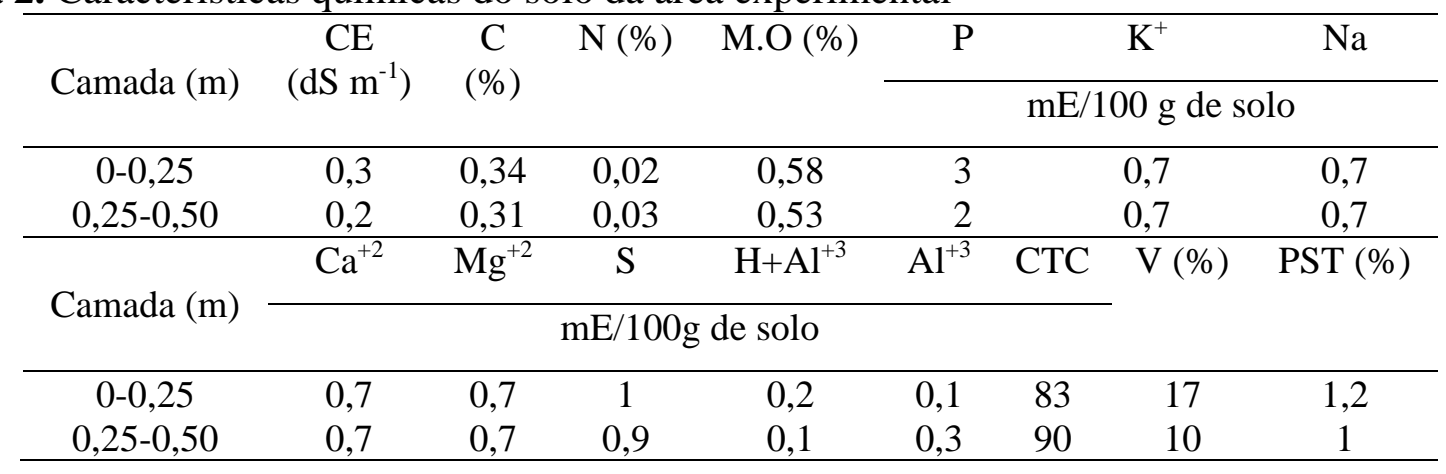

Durante os ciclos experimentais, foram monitorados e obtidos os dados meteorológicos de temperatura (média, máxima e mínima), umidade relativa do ar (média, máxima e mínima) e precipitação, obtidos na estação agrometeorológica da Universidade Federal do Ceará, a uma distância de 30 metros da área, conforme Tabela 3.

Tabela 3. Dados meteorológicos durante os ciclos experimentais

\begin{tabular}{cccccccc}
\hline \multirow{2}{*}{ Ciclo } & \multicolumn{3}{c}{ Temperatura do ar $\left({ }^{\circ} \mathrm{C}\right)$} & \multicolumn{3}{c}{ Umidade relativa (\%) } & Precipitação \\
\cline { 2 - 7 } & Média & Máxima & Mínima & Média & Máxima & Mínima & $(\mathrm{mm})$ \\
\hline 1 & 27,32 & 27,80 & 26,85 & 76,76 & 78,94 & 74,39 & 121,00 \\
2 & 26,81 & 27,32 & 26,33 & 69,78 & 72,17 & 67,25 & 33,80 \\
\hline
\end{tabular}

O delineamento experimental utilizado foi o inteiramente casualizado, com cinco tratamentos e seis repetições totalizando 30 unidades experimentais. Os tratamentos foram constituídos por: T1= lençol freático constante a $5 \mathrm{~cm}$ da superfície do solo; T2 = lençol freático constante a $10 \mathrm{~cm}$ da superfície do solo; $\mathrm{T} 3$ = lençol freático constante a $20 \mathrm{~cm}$ da superfície do solo, $\mathrm{T} 4=$ lençol freático constante a $30 \mathrm{~cm}$ da superfície do solo e T5 = testemunha (sem a presença de lençol freático). Os tratamentos foram posicionados 7 dias após emergência (DAE) e permaneceram até a colheita com 30 DAE.

A unidade experimental consistiu de lisímetros de drenagem com $3 \mathrm{~m}^{2}$ de área e 1,5 
m de altura (Figura 1). Os lisímetros foram dotados de um sistema de drenagem interna e abastecimento de água individual, por meio de um reservatório elevado situado ao lado dos mesmos, contendo um sistema de registros para regular a altura máxima da água no reservatório. A altura do nível freático foi controlada através de monitoramento realizado através de piezômetros em cada tratamento durante todo o ciclo.

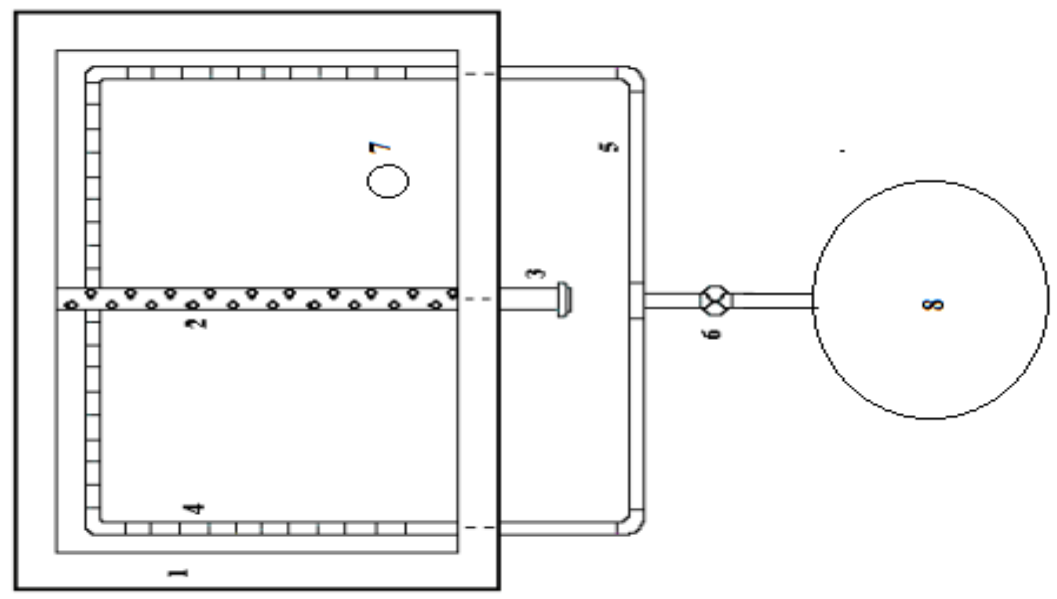

Figura 1. Planta baixa do lisímetro de drenagem com os seguintes componentes: 1 - área do lisímetro, 2 - dreno interno, 3 - saída da água drenada, 4 - sistema de abastecimento da água, 5 - tubulação de entrada, 6 - registro de controle do lençol, 7 - piezômetro, 8 - reservatório para manutenção do lençol.

A cultura utilizada foi o rabanete (Raphanus Sativus L.) com espaçamento de $0,10 \mathrm{~m}$ entre plantas e 0,20 entre fileiras, onde foram desprezadas as duas fileiras das bordas, assim como as duas primeiras e as duas últimas plantas de cada fileira, permanecendo, um total de 11 plantas por fileira, e 66 plantas úteis por unidade experimental. Utilizou-se três plantas por fileiras, escolhidas por acaso entre as demais, em um total de 11 plantas por fileira.

A semeadura foi realizada manualmente no sistema de plantio direto no dia 03/05/17 (primeiro ciclo) e 20/06/2017 (segundo ciclo) em sulcos com profundidade de $1-2 \mathrm{~cm}$, com espaçamento entre linhas de $0,20 \mathrm{~m}$. Foi utilizada a cultivar 'cometo' uma das mais cultivadas no Nordeste brasileiro. A adubação de plantio consistiu de $20 \mathrm{~L}$ de esterco bovino curtido por metro quadrado em cada tanque, em conformidade com a análise de solo (Tabela 2), previamente adquirida. Foram realizadas duas irrigações diárias nos primeiros dias para todos os tratamentos com a finalidade de manter o solo úmido, e não comprometer a germinação e desenvolvimento das plântulas.

O desbaste teve início aos 7 dias após a semeadura (DAE), quando aproximadamente
$80 \%$ das plantas se encontram com dois pares de folhas definitivas até a obtenção do espaçamento de $0,10 \mathrm{~m}$ entre plantas. A primeira adubação de cobertura foi realizada 7 DAE e a segunda 7 dias após a primeira, tomando como base a recomendação de adubação (SOUZA, 2010), com aplicação em plantio de $20.000 \mathrm{~kg} \mathrm{ha}^{-1}$ de composto orgânico e análise do solo. A lâmina de irrigação necessária do tratamento sem elevação do nível freático foi determinada pela evapotranspiração da cultura com coeficiente de cultivo (Kc): 0,45; 0,55; 0,95 e 0,65, para os estádios I, II, III e IV respectivamente, os dados climatológicos foram coletados da estação agrometeorologia da UFC.

A colheita foi realizada no dia 02/06/17 (primeiro ciclo) e 20/07/17 para o segundo ciclo. As plantas de cada unidade foram colhidas, acondicionadas em sacos de papelões e identificadas, posteriormente foram conduzidas para um processo de lavagem. Após a operação de lavagem em água corrente, foram cortadas a parte aérea rente à parte superior da raiz. Em seguida, iniciou-se as avaliações das variáveis: diâmetro médio da raiz (DMR) medida com paquímetro digital, altura média da 
raiz (AMR) medida com auxílio de trena, área foliar (ÁF) com o auxílio do medidor foliar LI300c , número de folhas (NF) através de contagem manual e posteriormente, massa fresca da raiz (MFR) e massa fresca da parte aérea (MFPA) através de balança de precisão de $0,01 \mathrm{~g}$, a massa seca da raiz (MSR) e massa seca da parte aérea (MSPA) foram obtidas através de pesagem após secagem em estufa com circulação forçada de ar á temperatura de $65^{\circ} \mathrm{C}$.

As avaliações de trocas gasosas foram realizadas antes da colheita com o medidor IRGA (Infra-Red Gas Analyser) modelo LI6400XT (Portable photosynthesis System - LI) da Licor ${ }^{\circledR}$, obtendo assim as seguintes variáveis: taxa de fotossíntese líquida (A), condutância estomática (gs); temperatura foliar $\left({ }^{\circ} \mathrm{C}\right)$, taxa de transpiração (E). As medições foram realizadas no horário compreendido entre 9:00 as 10:00 da manhã dos meses de maio a julho de 2017 nos dois ciclos de produção.
Os resultados foram submetidos ao teste de normalidade e posteriormente a análise de variância $(\mathrm{p}<0,05)$, as variáveis significativas foram submetidas ao teste de Tukey a 5\% de probabilidade. Para tanto foi utilizado o software SISVAR (FERREIRA, 2008).

\section{RESULTADOS E DISCUSSÃO}

\section{Analise de crescimento e rendimento}

A análise de variância (Tabela 4) apresentam a influência dos níveis freáticos sob as variáveis de crescimento. Verificou-se que os níveis de excesso de água no solo influenciaram significativamente $(p<0,01)$ todas as variáveis estudadas em ambos os ciclos de cultivo, o que demonstra a sensibilidade da cultura ao excesso de água.

Tabela 4. Análise de variância (Teste F) para as variáveis de crescimento da cultura do rabanete submetida a diferentes níveis freáticos

\begin{tabular}{|c|c|c|c|c|c|}
\hline \multirow[t]{2}{*}{ FV } & GL & DMR & AMR & ÁF & NF \\
\hline & & \multicolumn{4}{|c|}{-----------------------Ciclo 1 ------------------------ } \\
\hline Bloco & 5 & 7,12 & 7,48 & 4732 & 0,358 \\
\hline Tratamento & 4 & $2024,34 * *$ & $2762 * *$ & $305452 * *$ & $63,91 * *$ \\
\hline \multirow[t]{2}{*}{$\mathrm{CV}$} & & 9,47 & 14,78 & 20,24 & 11.23 \\
\hline & & \multicolumn{4}{|c|}{--------------------------Ciclo 2---------------------- } \\
\hline Bloco & 5 & 17,34 & 56,03 & 10602 & 0,67 \\
\hline Tratamento & 4 & $640,53 * *$ & $870,41^{* *}$ & $313686 * *$ & $9,13 * *$ \\
\hline $\mathrm{CV}$ & & 7,27 & 12,80 & 25,12 & 13,67 \\
\hline
\end{tabular}

O DMR (Figura 2) apresentou decréscimo nos seus valores à medida que o lençol freático se aproximou da superfície do solo. Os maiores valores para a variável DMR foram observados para T3, com média de 45,02 mm no ciclo 1 e 52,99 mm no ciclo 2 , sendo tais valores semelhantes inclusive aos valores obtidos por $\mathrm{T} 5$, conforme teste de Tukey a 5\% de probabilidade. A cultura quando submetida ao tratamento $\mathrm{T} 1$ não apresentou desenvolvimento no primeiro ciclo $(0 \mathrm{~mm})$, possivelmente devido a contribuição do regime pluviométrico no período (121 mm), que aumentou ainda mais a umidade do solo. 


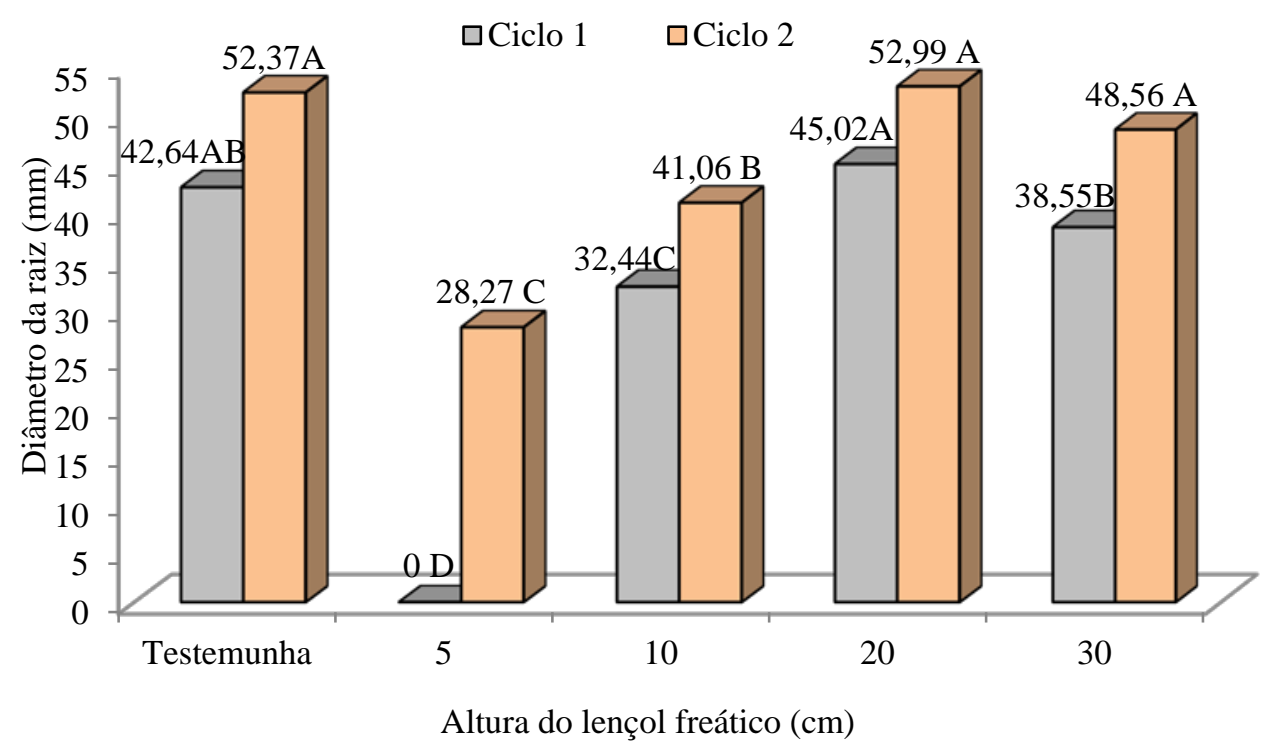

Letras iguais não diferem ao nível de 5\% de probabilidade pelo teste de Tukey. DMS (Ciclo 1):5,19; DMS (ciclo 2): 5,62 Figura 2. Diâmetro das raízes de rabanete submetidas a diferentes níveis freáticos em dois ciclos de produção

Trabalhando com a cultura da beterraba, Costa et al. (2008), observaram um comportamento similar, onde os níveis de estresse por excesso de água influenciaram diretamente nas variáveis de rendimento à medida que o nível freático estivesse mais próximo a superfície do solo. Contudo, Lacerda et al. (2017) em estudos sobre a cultura do rabanete observaram que a aplicação de $125 \%$ da evapotranspiração da cultura aumentaram o diâmetro da raiz da cultura, possivelmente o tratamento T3 $(20 \mathrm{~cm})$ proporcionou um fornecimento adequado para a cultura através da ascensão capilar ajudando no seu desenvolvimento.

Para a AMR (Figura 3) no ciclo 1, os maiores valores foram observados para os tratamentos T3 (50,6 mm) e T4 $(49,79 \mathrm{~mm})$ e para o tratamento $\mathrm{T} 5(46,58 \mathrm{~mm})$, enquanto o ciclo 2, observou-se que os tratamentos T2 $(53,38 \mathrm{~mm}) \mathrm{T} 3(58,24 \mathrm{~mm})$ e T4 $(53,54 \mathrm{~mm})$ além do tratamento $\mathrm{T} 5$ (60,46 $\mathrm{mm})$ não apresentaram diferenças entre si pelo teste de Tukey a $5 \%$ de probabilidade. Os menores valores foram observados para T1 (0 e 30,23 $\mathrm{mm})$ em ambos os ciclos e T2 (30,36 mm) para o primeiro ciclo. Tais valores foram semelhantes aos observados por Caetano et al., (2015) em estudos sobre doses de nitrogênio na cultura do rabanete, o que evidencia a baixa influência do excesso de água em relação a esta variável. 


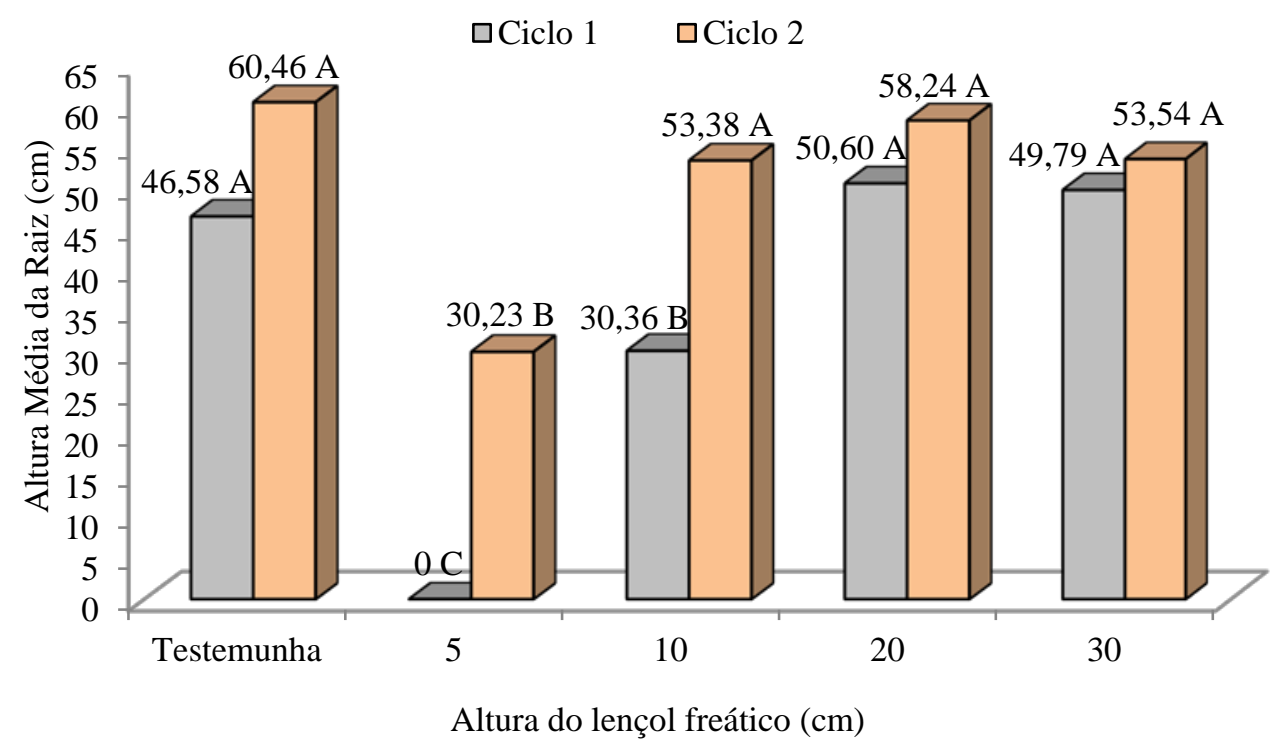

Letras iguais não diferem ao nível de 5\% de probabilidade pelo teste de Tukey. DMS (Ciclo 1):9,06; DMS (ciclo 2): 11,32

Figura 3. Altura média da raiz de rabanete submetidas a diferentes níveis freáticos em dois ciclos de produção

Para a variável ÁF (Figura 4) observa-se que a maior área foliar da cultura do rabanete submetida aos diferentes níveis freáticos nos dois ciclos de produção, foi encontrado nos tratamentos T3 e T4, obtendo valores superiores aos demais tratamentos. Comparado ao tratamento $\mathrm{T} 5$, observa-se maiores valores nos tratamentos T3 e T4 para o primeiro ciclo (509,38 e 517,81 cm² respectivamente). Já para o segundo ciclo, o tratamento de T3 $\mathbf{( 5 6 7 , 8 5}$ $\mathrm{cm}^{2}$ ) se mostrou superior aos demais tratamentos, conforme teste de Tukey a 5\% de probabilidade, sendo semelhante apenas ao tratamento T5 $\left(634,67 \mathrm{~cm}^{2}\right)$. Aumonde et al., (2011), destaca que a medida que decresce a taxa de área foliar, as taxas de matéria seca também decrescem. Assim, essa redução da área foliar a medida que os níveis freáticos se encontram mais próximos a superfície do solo, afeta negativamente os parâmetros de rendimentos da cultura.

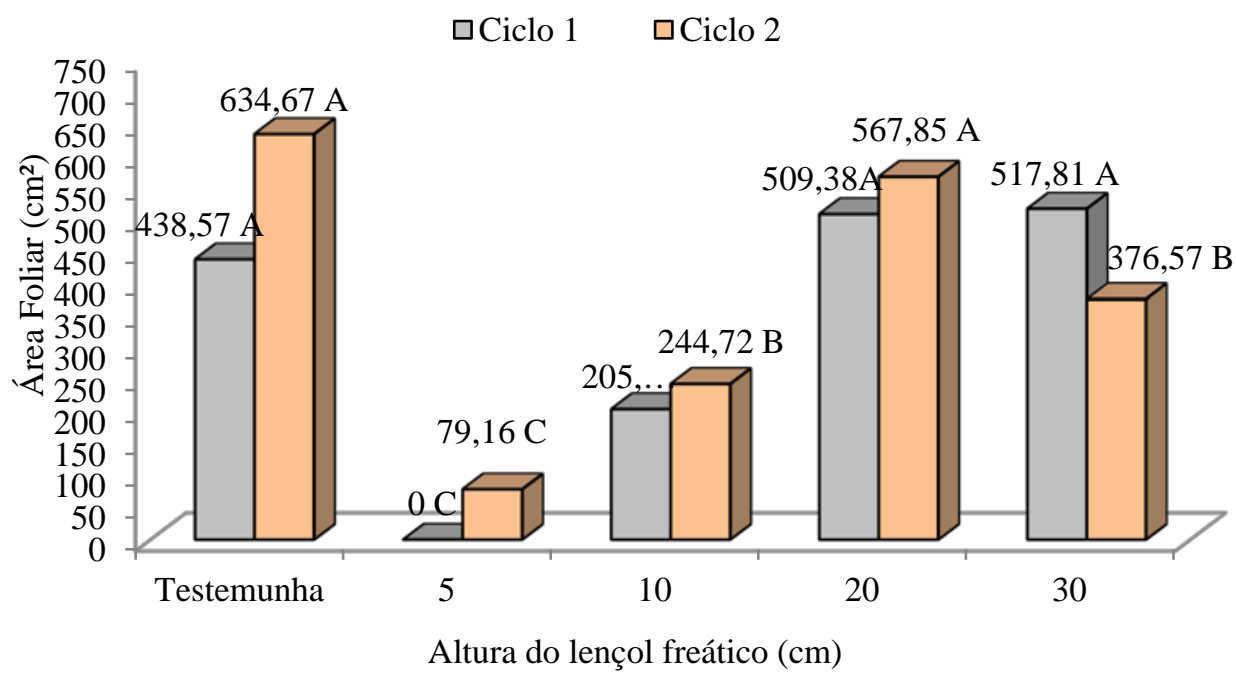

Letras iguais não diferem ao nível de 5\% de probabilidade pelo teste de Tukey. DMS (Ciclo 1):116,88; DMS (ciclo 2): 11,32

Figura 4. Área foliar da cultura do rabanete submetidas a diferentes níveis freáticos em dois ciclos de produção 
Para a variável NF (Figura 5) observase que o menor número de folhas da cultura do rabanete submetida a diferentes níveis freáticos nos dois ciclos de produção, foi encontrado quando se utilizou o nível freático a $5 \mathrm{~cm}$ da superfície do solo, conforme teste de Tukey a $5 \%$ de probabilidade. No ciclo 1 os tratamentos T2, T3, T4 e T5, não apresentaram diferenças entre si. Para o ciclo 2 observou-se que os tratamentos T3, T4 e T5 não apresentaram diferenças entre si, enquanto os tratamentos T1 e T2 foram semelhantes, conforme teste de Tukey a 5\% de probabilidade. Resultados semelhantes foram observados por Nobre et al., (2009) trabalhando com a cultura da alface, em que estes autores também observaram redução significativa na emissão foliar em resposta ao encharcamento do solo.

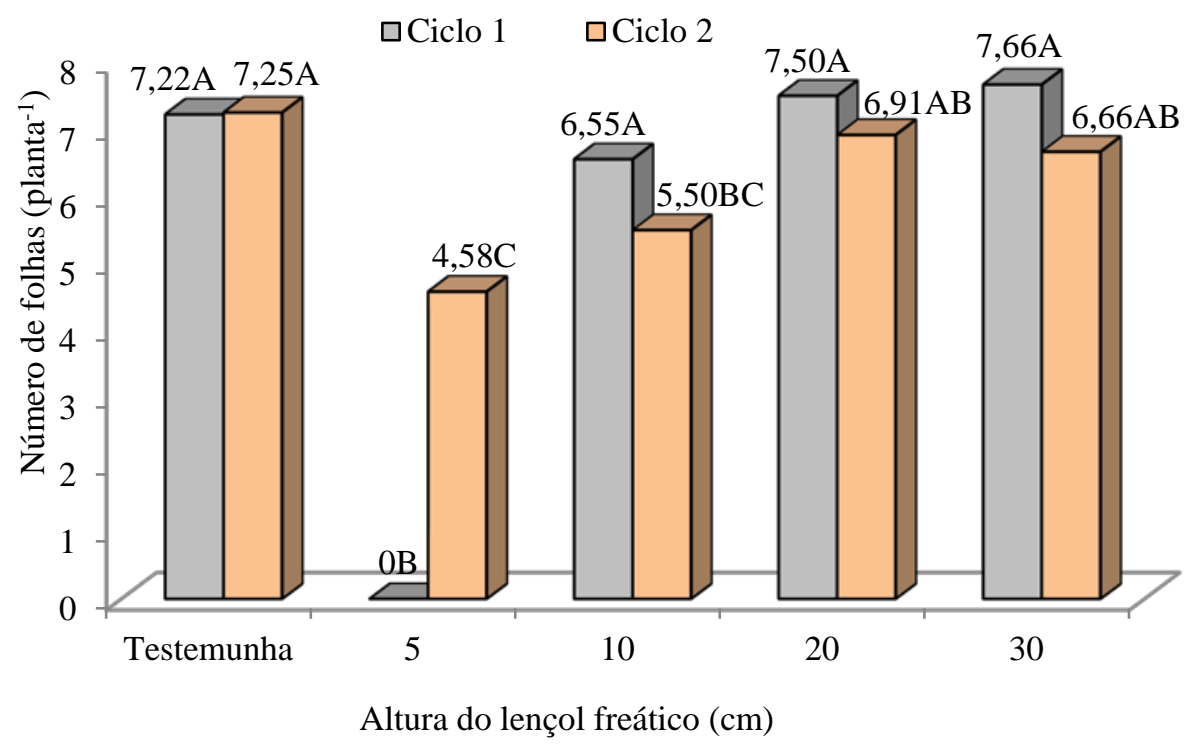

Letras iguais não diferem ao nível de 5\% de probabilidade pelo teste de Tukey. DMS (Ciclo 1):1,12; DMS (ciclo 2): 1,51

Figura 5. Número de folhas da cultura do rabanete submetidas a diferentes níveis freáticos em dois ciclos de produção

A tabela 5 demonstra a análise variância para as variáveis de rendimento da cultura do rabanete. De acordo com o teste $\mathrm{F}$, todas as variáveis apresentaram diferenças significativas para os tratamentos estudados ao nível de $1 \%$ de probabilidade $(\mathrm{p}<0,01)$. O que demonstra a sensibilidade da cultura a variação dos níveis de água no solo, discutido por Lacerda et al. (2017) e Rodrigues et al. (2013).

Tabela 5. Análise de variância (Teste F) para as variáveis de produção da cultura do rabanete submetida a diferentes níveis freáticos

\begin{tabular}{|c|c|c|c|c|c|}
\hline \multirow{2}{*}{ FV } & \multirow{2}{*}{ GL } & MFR & MFPA & MSR & MSPA \\
\hline & & \multicolumn{4}{|c|}{----------------------Ciclo 1 ------------------------ } \\
\hline Bloco & 5 & 64,42 & 5,54 & 0,02 & 0,02 \\
\hline Tratamento & 4 & $2461 * *$ & $862,62 * *$ & $0,55^{* *}$ & $0,94 * *$ \\
\hline \multirow[t]{2}{*}{$\mathrm{CV}$} & & 29,75 & 22,92 & 27,77 & 48,28 \\
\hline & & \multicolumn{4}{|c|}{-----------------------Ciclo 2-------------------- } \\
\hline Bloco & 5 & 271,47 & 91,01 & 0,052 & 0,13 \\
\hline Tratamento & 4 & $5173,38 * *$ & $1407,22 * *$ & $11,164 * *$ & $5,067^{* *}$ \\
\hline $\mathrm{CV}$ & & 17,35 & 29,03 & 12,38 & 25,64 \\
\hline
\end{tabular}

** e * significativo a 1 e $5 \%$ respectivamente

Para a variável MFR (Figura 6) observase que a menor produção, foi encontrada nos tratamentos T1 (0 g planta $\left.{ }^{-1}\right)$ e T2 $(18,09 \mathrm{~g}$ planta $\left.^{-1}\right)$ para o primeiro ciclo e $\mathrm{T} 1(15,17 \mathrm{~g}$ 


\section{CULTURA DO RABANETE}

planta $^{-1}$ ) para o segundo ciclo de produção. Conforme demonstrado por Costa et al. (2008) lençóis freáticos próximos a superfície são prejudiciais ao desenvolvimento de culturas com baixa tolerância ao encharcamento, o que torna inviável a produção em tais situações.

Os tratamentos T3(44,25 g planta $\left.^{-1}\right)$ e T4 $\left(41,78 \mathrm{~g} \mathrm{planta}^{-1}\right)$, proporcionaram um melhor desempenho no ciclo 1, enquanto para o ciclo 2, os tratamentos T3 $\left(82,52\right.$ g planta $\left.^{-1}\right)$ e T4 cm $\left(63,71\right.$ g planta $\left.^{-1}\right)$ apresentaram valores inferiores aos obtidos por T5 (89,06 g planta $\left.^{-1}\right)$. Segundo Pimentel (2004), o desenvolvimento do sistema radicular das plantas é reduzido sob condições de déficit hídrico. Lembrando que a cultura foi submetida a diferentes níveis freáticos e o que explica sua boa resposta de produção nos tratamentos T3 e T4, é exatamente as boas condições hídricas fornecidas a cultura por capilaridade.

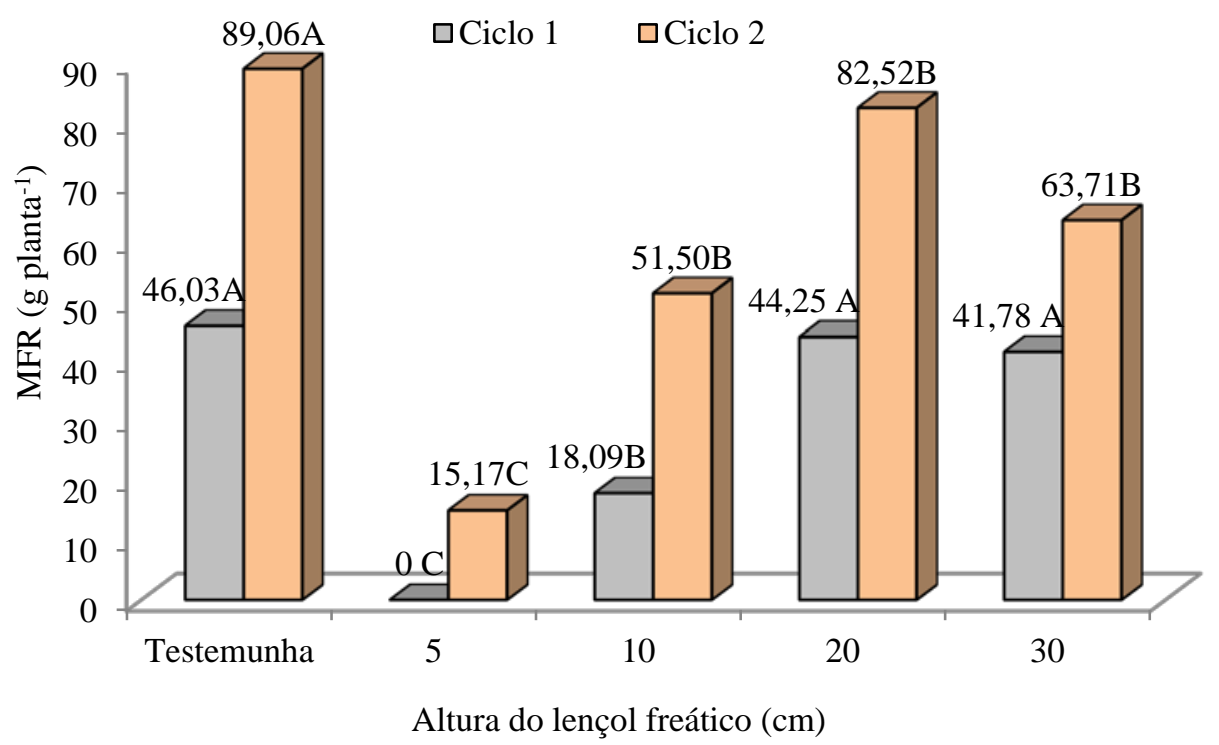

Letras iguais não diferem ao nível de 5\% de probabilidade pelo teste de Tukey. DMS (Ciclo 1):15,44; DMS (ciclo 2): 12,07

Figura 6. Massa de matéria fresca das raízes da cultura do rabanete submetidas a diferentes níveis freáticos em dois ciclos de produção

Para a MFPA (Figura 7) no primeiro ciclo, observa-se que os maiores valores foram obtidos nos tratamentos T3 e T4 com valores de 25,97 e 27,19 g planta $^{-1}$ respectivamente, em ambos os tratamentos a produção foi estatisticamente semelhante ao tratamento T5 (24,70 g planta $\left.{ }^{-1}\right)$. No segundo ciclo, os tratamentos T3 e T5 apresentaram os maiores valores dentre os demais tratamentos, com valores de 42,12, 36,77 g planta $^{-1}$ respectivamente. Carmichael et al., (2012) em estudos sobre a cultura do rabanete em Suazilândia, observaram acréscimos na produção da parte aérea da cultura em tratamentos com maiores disponibilidades de água no solo.

Pelos valores observados para os demais tratamentos, o excesso de água demonstrou ser prejudicial a partir de $10 \mathrm{~cm}$ de profundidade, tendo reduções superiores a 70\% em relação ao tratamento T5 no ciclo 2 . Resultados que reforçam esta possibilidade podem ser observados em Tomassoni et al., (2013) em experimento com couve-flor sob diferentes níveis freáticos, onde estes autores observaram redução da massa fresca da cultura, conforme aproximação do lençol freático a superfície do solo. 


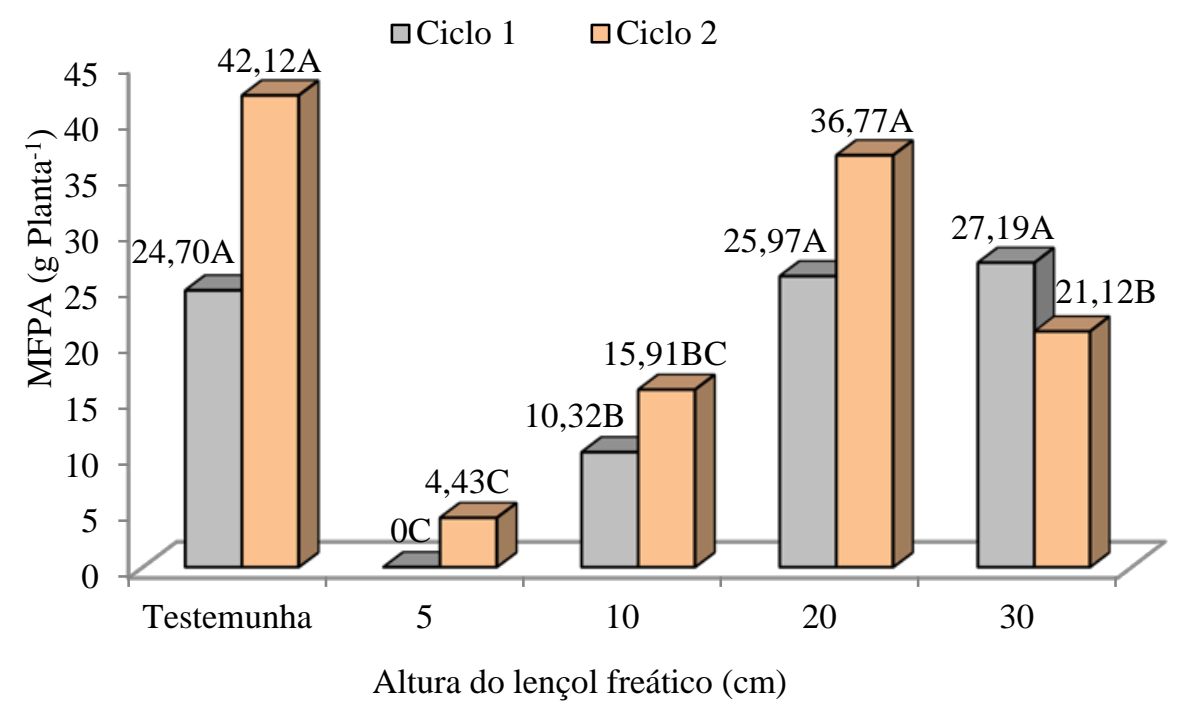

Letras iguais não diferem ao nível de 5\% de probabilidade pelo teste de Tukey. DMS (Ciclo 1):6,98; DMS (ciclo 2): 12,07 Figura 7. Massa de matéria fresca da parte aérea da cultura do rabanete submetidas a diferentes níveis freáticos em dois ciclos de produção

A MSR (Figura 8) apresentou decréscimo à medida que o estresse por excesso de água era maior para os dois ciclos, porém esse comportamento ficou mais evidenciado no segundo ciclo. Observa-se no primeiro ciclo, que os maiores valores para a varável MSR foi obtida no tratamento T5 (075 g planta $\left.^{-1}\right)$ e T4 $\left(0,64 \mathrm{~g}\right.$ planta $\left.^{-1}\right)$ sendo estes semelhantes estatisticamente pelo teste de Tukey a $5 \%$ de probabilidade. Para o segundo ciclo, esse comportamento foi similar, porém destacasse a superioridade no rendimento da MSR em relação ao ciclo 1 . No ciclo 2, os tratamentos T3 e T4 apresentaram maiores MSR (3,98 e 3,70 g planta $^{-1}$ ) em relação aos demais tratamentos, contudo o tratamento T3 apresentou menor valor em relação ao tratamento T5 $(4,56 \mathrm{~g}$ planta $\left.^{-1}\right)$. Os valores obtidos no ciclo 2 se assemelham aos obtidos por Caetano et al. (2015) que obtiveram valores máximos de 3,36 g planta ${ }^{-1}$. Possivelmente os baixos valores observados no ciclo 1 podem ser explicados pelas condições climáticas (excessiva chuva) ocorridas na época de plantio, desfavorecendo assim um melhor desenvolvimento da cultura (FILGUEIRA, 2008).

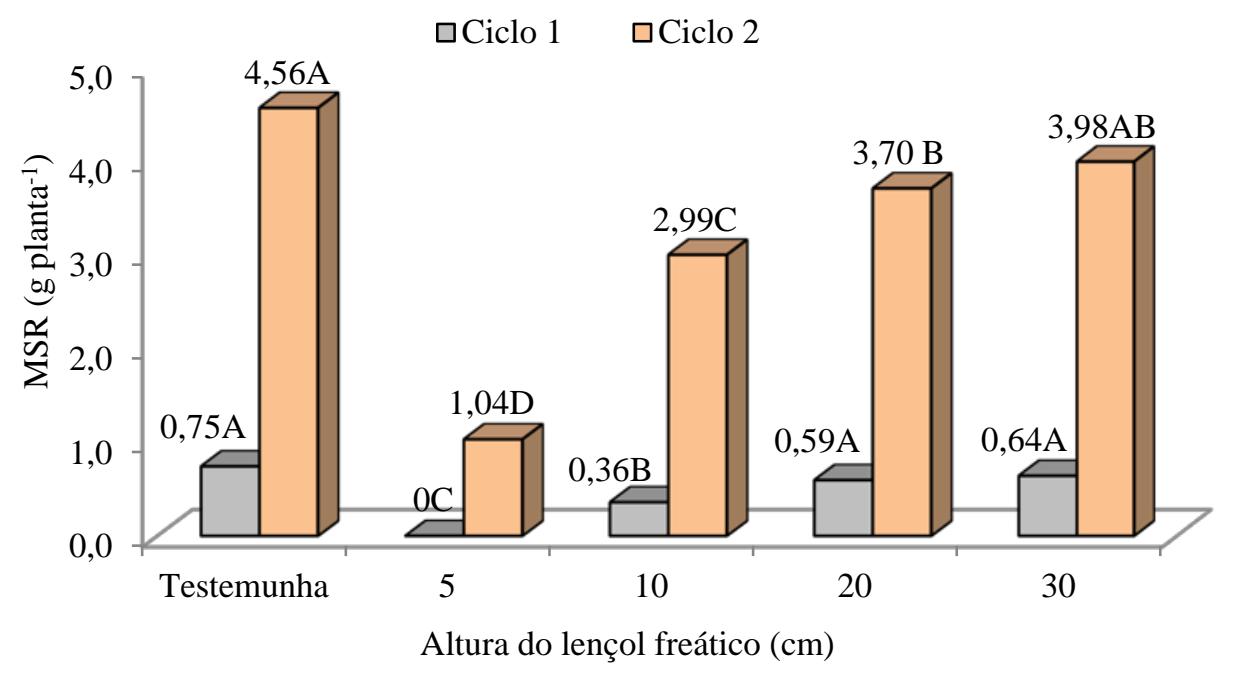

Letras iguais não diferem ao nível de 5\% de probabilidade pelo teste de Tukey. DMS (Ciclo 1):0,22; DMS (ciclo 2): 0,69

Figura 8. Massa de matéria seca das raízes da cultura do rabanete submetidas a diferentes níveis freáticos em dois ciclos de produção 
Para a MSPA (Figura 9) os maiores valores, nos dois ciclos foram observados nos tratamentos T3 $\left(0,84\right.$ e 2,42 g planta $\left.^{-1}\right)$ e T4 cm $\left(0,89\right.$ e 2,08 g planta $\left.^{-1}\right)$ e T5 $(0,77$ e 3,15 g planta $\left.^{-1}\right)$. $\mathrm{O}$ tratamento $\mathrm{T} 1$ diminuiu significativamente os valores de MSPA nos dois ciclos $\quad\left(\begin{array}{lllll}0 & \text { e } & 0,77 & \text { g } & \text { planta }^{-1}\end{array}\right.$ respectivamente), esta diminuição está diretamente relacionada ao excesso de água presente no sistema radicular da planta (COSTA et al., 2008), desfavorecendo o seu desenvolvimento e por consequência a matéria seca das plantas.

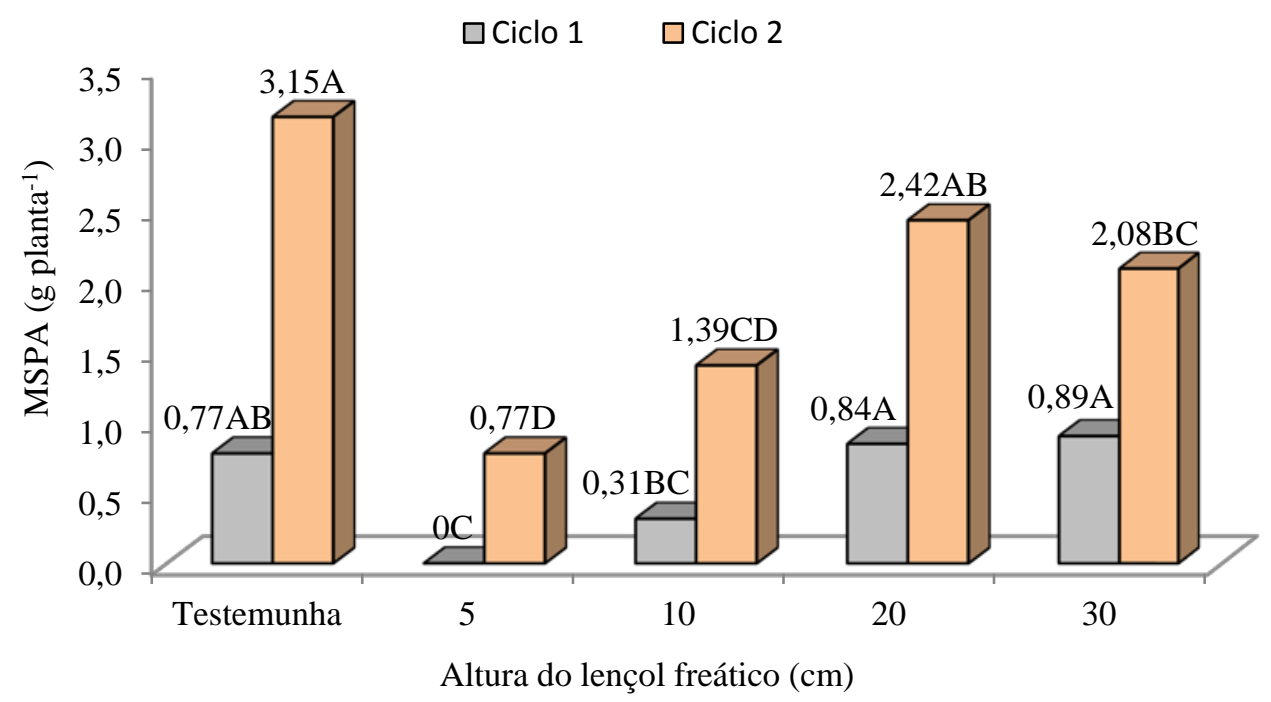

Letras iguais não diferem ao nível de 5\% de probabilidade pelo teste de Tukey. DMS (Ciclo 1):0,22; DMS (ciclo 2): 0,87

Figura 9. Massa de matéria seca da parte aérea da cultura do rabanete submetida a diferentes níveis freáticos em dois ciclos de produção

\section{Trocas gasosas}

Pela análise de variância (Tabela 6), verificou-se que os níveis de estresses pelo excesso de água no solo influenciaram significativamente $(\mathrm{p}<0,01)$ todas as variáveis estudadas para o ciclo 1 e a variável condutância estomática (A), para o ciclo 2.

Tabela 6. Análise de variância (Teste F) para as trocas gasosas da cultura do rabanete submetida a diferentes níveis freáticos

\begin{tabular}{|c|c|c|c|c|c|}
\hline \multirow{2}{*}{ FV } & \multirow{2}{*}{ GL } & A & gs & $\mathrm{E}$ & Tf \\
\hline & & \multicolumn{4}{|c|}{--------------------'Ciclo 1 ---------------------- } \\
\hline Bloco & 5 & 2,64 & 0,43 & 0,22 & 0,29 \\
\hline Tratamento & 4 & $632,08 * *$ & $73,3^{* *}$ & $127,83^{* *}$ & $1282,21 * *$ \\
\hline \multirow[t]{2}{*}{$\mathrm{CV}$} & & 9,50 & 10,0 & 5,57 & 5,57 \\
\hline & & ---------- & --------- & iclo 2------ & --------- \\
\hline Bloco & 5 & 3,76 & 0,05 & 2,77 & 0,48 \\
\hline Tratamento & 4 & $32,20^{*}$ & 0,05 & 5,88 & 0,66 \\
\hline $\mathrm{CV}$ & & 12,31 & 24,80 & 10,33 & 2,46 \\
\hline
\end{tabular}

Taxa de fotossíntese líquida (A), Condutância Estomática ( $g s)$; Transpiração $(E)$;Temperatura da folha (Tf).

Para a variável A (Figura 10), o primeiro ciclo mostrou maiores valores no tratamento T3, T4 e T5, com 23,8, 23,4 e 23,8 $\mu$ mol de $\mathrm{CO}_{2}$ $\mathrm{m}^{-2} \quad \mathrm{~s}^{-1} \quad$ respectivamente, divergindo estatisticamente dos demais tratamentos. No segundo ciclo os tratamentos $\mathrm{T} 5$ e $\mathrm{T} 4$, divergiram estatisticamente dos demais tratamentos, com valores de 26,0 e $24,7 \mu \mathrm{mol}$ de $\mathrm{CO}_{2} \mathrm{~m}^{-2} \mathrm{~s}^{-1}$.

Em ambos os ciclos a fotossíntese liquida reduziu linearmente com a aproximação do lençol freático na superfície do solo ou seja, nos 
tratamentos com maiores estresses por excesso de água, tais resultados são reforçados pelo trabalho de Santos et al., (2016), estudando crescimento de rabanete em função de períodos de convivência com plantas daninhas, onde estes autores observaram uma redução na taxa de assimilação de fotossíntese liquida em função da redução nos valores de massa seca destas plantas, em decorrência dos efeitos da competição excedida pelas plantas ou seja, o estresse causou redução nesta variável.

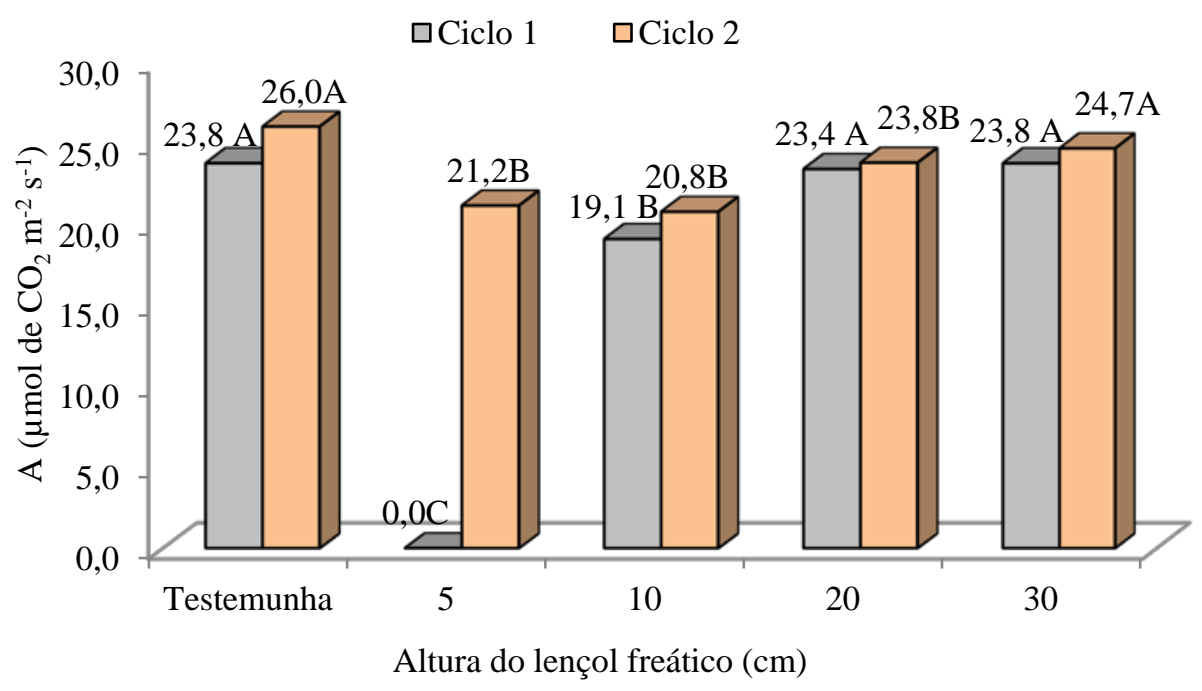

Letras iguais não diferem ao nível de 5\% de probabilidade pelo teste de Tukey. DMS (Ciclo 1):2,95; DMS (ciclo 2):4,93

Figura 10. Teste de Tukey a $5 \%$ de probabilidade para a variável fotossíntese líquida (A) em dois ciclos de produção

Para a variável gs (Figura 11) no primeiro ciclo, os tratamentos $\mathrm{T} 4$ e T5, obtiveram os maiores valores com 0,86 e $0,82 \mathrm{~mol} \mathrm{~m}^{2} \mathrm{~s}^{-1}$ respectivamente. Os tratamentos $\mathrm{T} 2$ e $\mathrm{T} 3$ apresentaram resultados semelhantes entre si conforme teste de Tukey a $5 \%$ de probabilidade. Com relação ao segundo ciclo, não foi observado diferença estatística entre tratamentos estudados.

A variável gs apresenta uma relação direta com a transpiração, quando as plantas fecham os estômatos diminui a taxa de transpiração e consequentemente diminui a perda de água para a atmosfera. Dependendo da quantidade de água disponível e a temperatura do ambiente a planta aciona o mecanismo de fechamento ou abertura dos estômatos. Segundo Demuner et al., (2017), estudando emergência plântulas de tomate sobre diferentes tensões de retenção de água no solo, percebeu que as plântulas respondem positivamente às condições mais favoráveis de água no solo, mantendo taxas fotossintéticas elevadas, proporcionando uma maior produção de fotoassimilados, implicando em maiores produções de matéria fresca. 


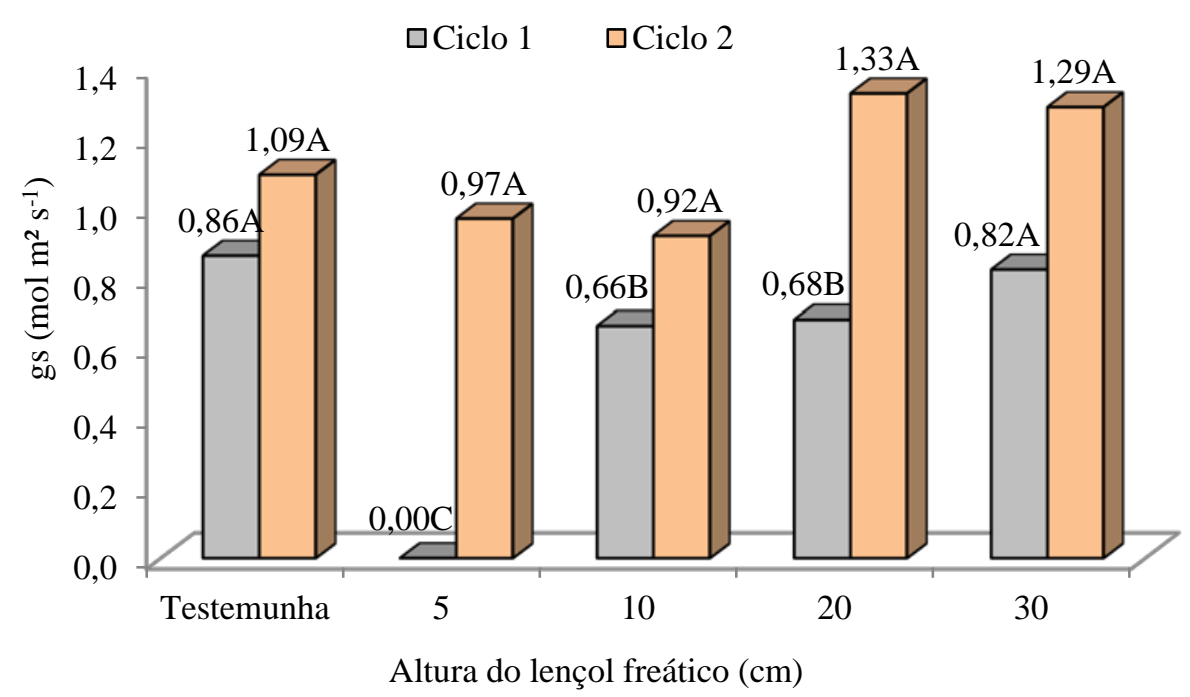

Letras iguais não diferem ao nível de 5\% de probabilidade pelo teste de Tukey. DMS (Ciclo 1):0,10; DMS (ciclo 2):0,45

Figura 11. Teste de Tukey a $5 \%$ de probabilidade para a variável condutância estomática (gs) em dois ciclos de produção

Para a variável E (Figura 12) observouse um comportamento semelhante a variável gs. No primeiro ciclo as maiores taxas de transpiração foram encontradas nos tratamentos T3 e T4, divergindo estatisticamente dos demais pelo teste de Tukey a $5 \%$ de probabilidade. No segundo ciclo, não houve diferença estatística entre os tratamentos. Desempenhos idênticos entre condutância estomática e transpiração são esperados, segundo Gonçalves et al., (2010) existe uma relação direta entre as taxas de transpiração e de condutância estomática, uma vez que, segundo estes autores, o fechamento estomático induz uma diminuição do fluxo de vapor d'água para a atmosfera, e, consequentemente, da quantidade de água transpirada.

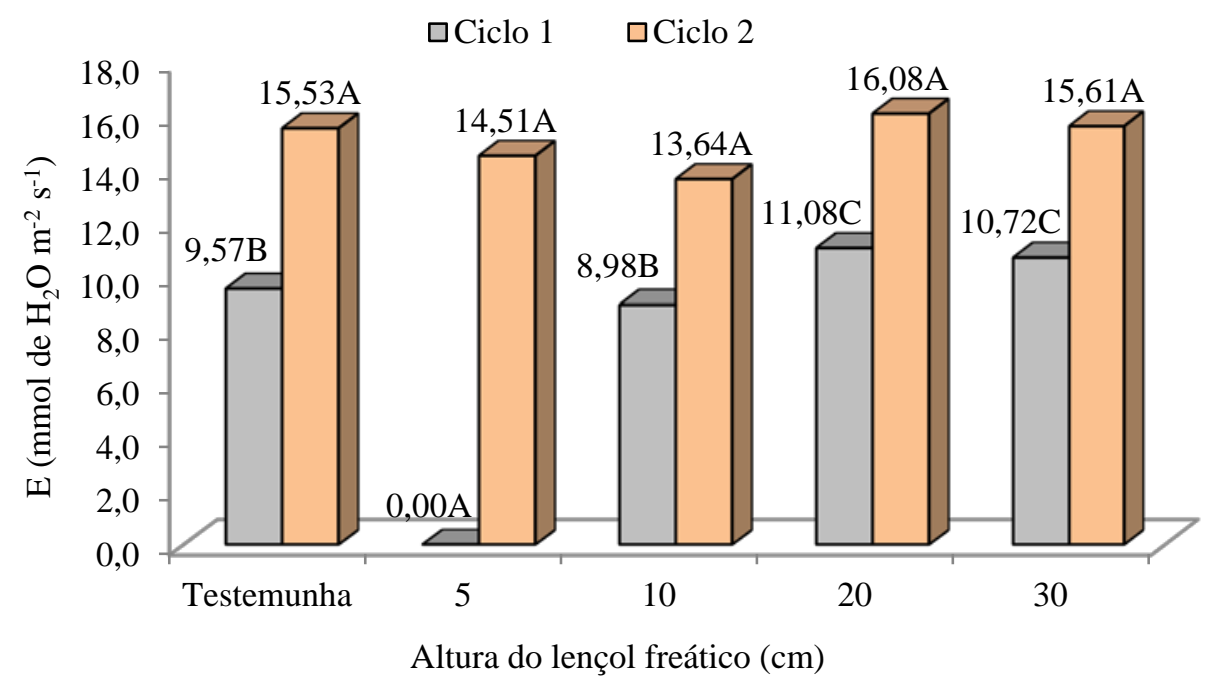

Letras iguais não diferem ao nível de 5\% de probabilidade pelo teste de Tukey. DMS (Ciclo 1):0,78; DMS (ciclo 2): 2,69

Figura 12. Teste de Tukey a 5\% de probabilidade para a variável transpiração (E) em dois ciclos de produção

Para a variável Tf (Figura 13), no primeiro ciclo de produção, verifica-se que a maior temperatura foliar foi observada nos tratamentos $\mathrm{T} 3\left(34,41^{\circ} \mathrm{C}\right)$ e $\mathrm{T} 4\left(32,86^{\circ} \mathrm{C}\right)$, os valores de ambos são superiores ao tratamento T5 $\left(31,25{ }^{\circ} \mathrm{C}\right)$. Ainda no primeiro ciclo é observado que o tratamento T1, foi obtido valor de temperatura da folha igual à zero, isso 
devido à ausência da cultura que não se desenvolveu nesse tratamento. No segundo ciclo não houve diferença estatística pelo teste de Tukey a 5\% de probabilidade para os tratamentos estudados.

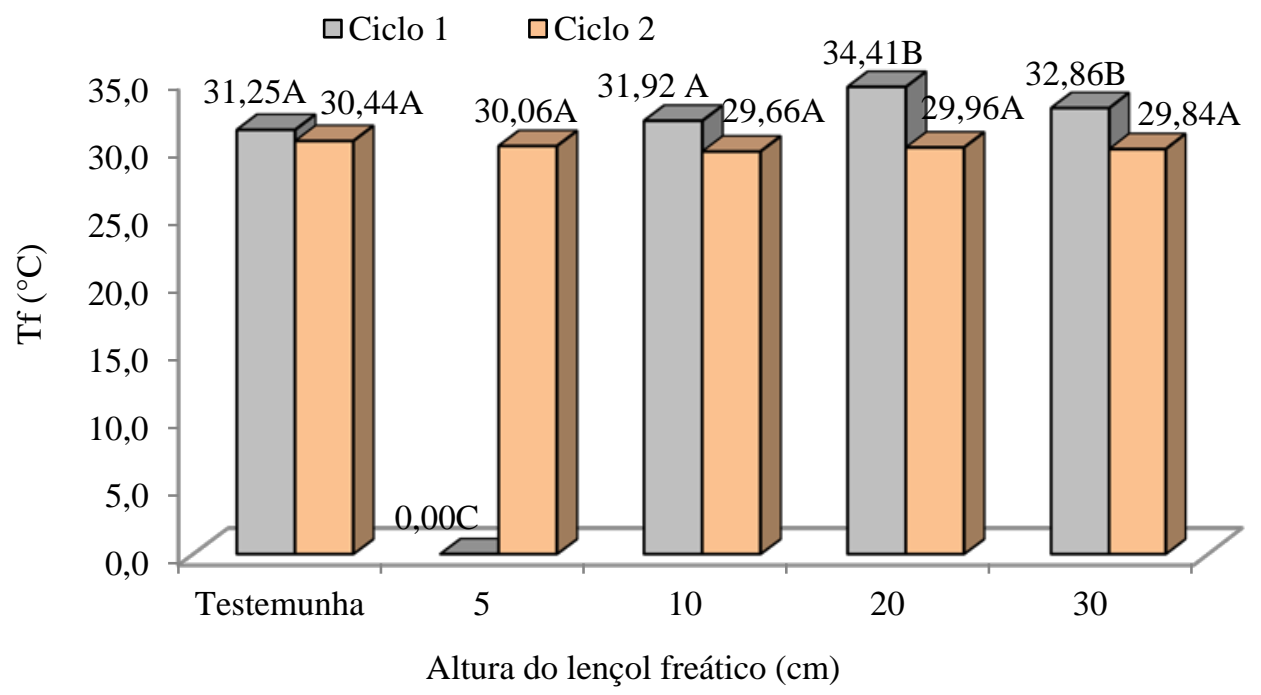

Letras iguais não diferem ao nível de 5\% de probabilidade pelo teste de Tukey. DMS (Ciclo 1): 0,77; DMS (ciclo 2):1,27

Figura 13. Teste de Tukey a $5 \%$ de probabilidade para a variável Temperatura foliar (Tf) em dois ciclos de produção

\section{CONCLUSÕES}

As características de desenvolvimento e produtividade da cultura do rabanete são afetadas negativamente com lençóis freáticos mantidos nas profundidades de 5, 10 e $15 \mathrm{~cm}$ de profundidade em relação a superfície do solo.

O lençol freático mantido a $20 \mathrm{~cm}$ da superfície do solo, mostrou-se adequado para a cultura, sendo recomendável no manejo de produção do rabanete, possibilitando melhor desenvolvimento e maior produtividade das plantas.

\section{REFERÊNICAS}

ARAGÜÉS, R.; URDANOZ, V.; ÇETIN, M.; KIRDA, C.; DAGHARI, H.; LTIFI, W.; LAHLOU, M.; DOUAIK, A. Soil salinity related to physical soil characteristics and irrigation management in four Mediterranean irrigation districts. Agricultural Water Management, v.98, p.959-966, 2011. https://doi.org/10.1016/j.agwat.2011.01.004.

AUMONDE, T. Z.; LOPES, N. F.; MORAES, D. M.; PEIL, R. M. N.; PEDÓ, T. Análise de
Crescimento do híbrido de mini melancia Smile enxertada e não enxertada. Interciencia, v. 36, n. 9, p. 677-681, 2011.

CAETANO, A. O.; DINIZ, R. L. C.; BENETT, C. G. S.; SALOMÃO, L. C. Efeito de fontes e doses de nitrogênio na cultura do rabanete. Revista Agricultura Neotropical, v.2, n.4, p. 55-59, 2015. https://doi.org/10.32404/rean.v2i4.286.

CARMICHAEL, P. C.; SHONGWE, V. D.; MASARIRAMBI, M. T.; MANYATSI, A. M. Effect of mulch and irrigation on growth, yield and quality of radish (Raphanus sativus L.) in a semi-arid sub-tropical environment. Asian Journal of Agricultural Sciences, v. 4, n. 3, p. 183-187, 2012.

COSTA, C. C.; OLIVEIRA, C. D.; SILVA, C. J.; TIMOSSI, P. C.; LEITE, I. C. Crescimento, produtividade e qualidade de raízes de rabanete cultivadas sob diferentes fontes e doses de adubos orgânicos. Horticultura Brasileira, v. 24, p. 118-122, 2006.

COSTA, R. N. T.; VASCONCELOS, J. P.; SILVA, L. A.; NESS, R. L. L. Interferência do 
excesso de água no solo e componentes de produção em beterraba. Horticultura Brasileira, v. 26, n. 1, p.74-77, 2008. http://dx.doi.org/10.1590/S010205362008000100014.

DEMUNER, A. P. V.; MEIRELES, R. C.; REIS, L. S.; VIEIRA, G. H. S.; GARCIA, W. A.; Zinger, L.; Pires, A. A. Emergência de plântulas de tomate (Solanum lycopersicum L.) em diferentes tensões de retenção de água no solo. Revista Thema, v. 14, n. 4, p. 14 - 24, 2017.

http://dx.doi.org/10.15536/thema.14.2017.4454.756 .

EMPRESA BRASILEIRA DE PESQUISA AGROPECUÁRIA - EMBRAPA. Sistema brasileiro de classificação de solos. 3.ed. Brasília: Embrapa, 2013. 353p.

FERREIRA, D. F. SISVAR: um programa para análises e ensino de estatística. Revista Symposium, v.6, p.36-41, 2008.

FILGUEIRA, F. A. R. Novo manual de olericultura: Agrotecnologia moderna na produção e comercialização de hortaliças. 2. ed. Viçosa, MG: Editora UFV, 2008. 421p.

GONÇALVES, E. R.; FERREIRA, V. M.; SILVA, J. V.; ENDRES, L.; BARBOSA, T. B.; DUARTE, W. G. Trocas gasosas e fluorescência da clorofila a em variedades de cana-deaçúcar submetidas à deficiência hídrica.

Revista Brasileira de Engenharia Agrícola e Ambiental, v. 14, n. 4, p. 378-386, 2010. http://dx.doi.org/10.1590/S141543662010000400006.

LACERDA, V. R.; GONÇALVES, B. G.; OLIVEIRA, F. G.; SOUSA, Y. B.; CASTRO, I. L. Caracteristicas morfológicas e produtivas do rabanete sob diferentes lâminas de irrigação.

Revista Brasileira de Agricultura Irrigada, v.11, n.1, p.1127-1134, 2017. https://doi.org10.7127/rbai.v11n100513.

MUNDSTOCK, C. M.; SCHOENFELD, R.; ALMEIDA, D.; UHRY JUNIOR, D. F.;
CARLOS, F. S.; ZANON, A. J.; ULGUIM, A. R.; OGOSHI, C. ; MARCOLIN, E.; MORAIS, F. A.; BADINELLI, P. G.; SILVA, P. R. F.; ANGHINONI, I. SOJA 6000: Manejo para alta produtividade em terras baixas. Porto Alegre: Gráfica e Editora RJR, 2017. 68 p.

NOBRE, R. G.; FERNANDES, P. D.; GHEYI, H. R.; BRITO, M. E. B.; SILVA, L. A. Crescimento da alface sob saturação temporal do solo. Revista Brasileira de Engenharia Agrícola e Ambiental, v.13, (Suplemento), p.890-898, 2009. http://dx.doi.org/10.1590/S141543662009000700011.

OLIVEIRA, F. R. A; OLIVEIRA, F. A.;MEDEIROS, J. F.; SOUSA, V. F. L.; FREIRE, A. G. Interação entre salinidade e fósforo na cultura do rabanete. Revista Ciência Agronômica, v. 41, n. 4, p. 519-526, 2010.

PEREIRA, A. J.; BLANK, A. F.; SOUZA, J. R. OLIVEIRA, P. M.; LIMA, L. A. Efeito dos níveis de reposição e freqüência de irrigação sobre a produção e qualidade do rabanete. Revista de Engenharia Agrícola e Ambiental, v. 3, n. 1, p. 117-120, 1999.

PIMENTEL, C. A relação da planta com a água. Seropédica: Edur, 2004. 191 p.

RODRIGUES, R. R.; PIZETTA, S. C.; TEIXEIRA, A. G.; REIS, E. F.; HOTT, M. O. Produção de rabanete em diferentes disponibilidades de água. Enciclopédia Biosfera, v.9, n.17, p. 2121-2130, 2013.

SANTOS, V. M.; SILVA, L. L.; RAMOS, P. C.; SIEBENEICHLER, S. C.; CARDOSO, D. P.; SILVA, A. R. Análise do crescimento de rabanete em função de períodos de convivência com plantas daninhas. Revista Agrarian, v.9, n.34, p. 303311, 2016. https://doi.org/10.21206/rbas.v5i1.245.

SILVA, R. T.; SOUZA, A. A. T.; OLIVEIRA, F. A.; TARGINO, I. S. O.; SILVA, M. L. N. Tolerância do rabanete ao encharcamento do 
solo. Revista Verde, v. 7, n.1, p. 25-33, 2012. SOUZA, J. L. Sistema orgânico de produção de tomate. In: Instituto Capixaba de Pesquisa, Assistência Técnica e Extensão Rural. Tomate. Vitória, ES: Incaper, 2010. 67p.
TOMASSONI, F.; SANTOS, R. F.; ROCHA, A. A.; GALDINO, T. S. NADALETI, W. C.; ROSSI, E.; CARPINSKI, M. Sensibilidade do couve-flor ao excesso de água no solo. Acta Iguazu, v.2, n.4, p. 1-6, 2013. 